Oncology 1991;48:I-VI

\title{
Contents, Vol. 48,1991
}

\section{No. 1}

Original Paper

High-Dose Medroxyprogesterone Acetate versus Oophorectomy as First-Line Therapy of Advanced Breast Cancer inPremenopausal PatientsMartoni, A.; Longhi, A.; Canova, N.; Pannuti, F 1

Chemotherapy (CAP) for the Treatment of Advanced OvarianCancer and Second-Effort Surgery in the Second LookOjeda-Gonzalez, M.B.; Alvarez-Lopez, I.; Alonso-Mufioz, M.C.; BadiaSerra, J.; Delgado-Latre, E.; de Andres-Ba-sauri, L.; Lopez-Lopez, J.J 7 Immunosuppressive Acidic Protein and CA 125 Levels in Patients with Ovarian Cancer Castelli, M.; Battaglia, F.; Scambia, G.; Benedetti Panici, P.; Ferrandina, G.; Mileo, A.M.; Mancuso, S.; Ferrini, U. 13

Phase II Study of Continuous Venous Infusion of 5-Fluoro-uracil in Advanced Pancreatic CancerTajiri, H.: Yoshimori, M.; Okazaki, N.; Miyaji, M 18

Does Serum CAR-3 Play a Role in Pancreatic Cancer Diagnosis?

Basso, D.; Panozzo, M.P.; Fabris, C; Meggiato, T.; Fag-gian, D.; Fogar, P.; Scalon, P.; Del Favero, G.; Plebani, M.;Burlina, A.; Naccarato. R 22 Diagnostic Aspects and Follow-Up of 174 Cases of Hepatocellular Carcinoma. Second Report Buscarini, L.; Fornari, F.; Canaletti, R.; Sbolli, G; Civardi, G.; Cavanna, L.; Di Stasi, M 26 Can a Patient with Neuroblastoma Be Diagnosed by a SingleUrine Sample Collected Randomly?Nishi, M.; Miyake, FL; Takeda, T.; Takasugi, N.; Hanai, J.;Kawai, T 31 Human Hepatocellular Carcinoma Sensitivity to Antitumor Drugs Assayed Using the Succinate Dehydrogenase Inhibition Test

Kanematsu, T.; Maehara, Y.; Matsumata, T.; Shirabe, K.;Akazawa, K.; Sugimachi, K

DNA Flow Cytometry in the Prognosis of Primary Malignant Melanoma

Bartkowiak, D.; Schumann, J.; Otto, F.J.; Lippold, A.;Drepper, H 39

Suicide Risk among Incident Cases of Cancer in the SwissCanton of VaudLevi, F.; Bulliard, J.-

L.; La Vecchia, C 44

Diffuse Well Differentiated Lymphocytic Lymphoma: A Clinical Study of 22 Patients Adelstein, D.J.; Henry, M.B.; Bowman, L.S.; Hines, J.D. 48

Clodronate Treatment Increases Serum Osteocalcin in Nor-mocalcemic Osteolytic Bone MetastasesConte, N.; Di Virgilio, R.; Da Rin, G.; Roiter, I.; Pavan, P.;Legovini. P.; Foscolo, G 54

Effects of Retinoic Acid and Bromodeoxyuridine on Human Melanoma-Associated Antigen Expression in Small Cell Lung Carcinoma Cells Feyles, V.; Sikora, L.K.J.; McGarry, R.C.; Jerry, L.M. . . 58 Immunologic and Immunohistochemical Studies on Chronic Lymphocytic Thyroiditis with or without Thyroid Lymphoma Aozasa, K.; Tajima, K.; Tominaga, N.; Katagiri, S.; Yone-zawa, T.; Matsuzuka, F.; Kuma, K.; Sawada, M 65 
Sterol and Triterpene Derivatives from Plants Inhibit the Effects of a Tumor Promotor, and Sitosterol and Betulinic Acid Inhibit Tumor Formation in Mouse Skin Two-Stage Carcinogenesis Yasukawa, K.; Takido, M.; Matsumoto, T.; Takeuchi, M.;Nakagawa, S 72 Inhibition of 12-0-Tetradecanoylphorbol-13-Acetate-Promot-ed Mouse Skin Papilloma by Saponins Tokuda, H.; Konoshima, T.; Kozuka, M.; Kimura, T. . . 77

The Response of Mouse Tumours to Fractionated Doses ofPions: Determination of Therapeutic Gain FactorOgawa, Y.; Goodman, G.B.; Chaplin, D.J.; Grulkey, W.;Lam, G.K.Y 81 Book Reviews $\quad 88$

No. 2

Original Paper

Ifosfamide and Mesna for the Treatment of Advanced Squamous Cell Head and Neck Cancer. A Getlac StudyCervellino, J.C.; Araujo, C.E.; Pirisi, C; Francia, A.;Cerruti, R 89

Combination of Idarubicin and Cyclophosphamide Administered Orally in Untreated Postmenopausal Breast CancerPatients. A Phase II StudyKolaric, K.; Mechl, Z 93 Controlled Clinical Study on the Use of Dichloromethylene Diphosphonate in Patients with Breast Carcinoma Metastasizing to the Skeleton

Martoni, A.; Guaraldi, M.; Camera, P.; Biagi, R.; Marri, S.;Beghe, F.; Pannuti, F 97

Cimetidine and Coumarin Therapy of Renal Cell Carcinoma.A Pilot StudyKokron, O.; Maca, S.; Gasser, G; Schmidt, P.R 102

Polymorphic Oxidation of Debrisoquine in Women with Breast Cancer

Ladero, J.M.; Bem’tez, J.; Jara, C; Llerena, A.; Valdivielso, M.J.; Munoz, J.J.; Vargas, E 107

IV

Contents

The Antiemetic Activity of High-Dose Metoclopramide and High-Dose Alizapride in Combination with Lorazepam in Patients Receiving Cancer Chemotherapy. A Prospective, Randomized Double-Blind Study

Molino, A.; Guglielmo, L.; Azzolini, M.E.; Biondani, P.;Capelli, M.C.; Grandinetti, A.; Griso, C; Martinelli, G;Martini, N.; Zanotti, R.; Cetto, G.L Ill

Antiemetic Efficacy of Droperidol of Metoclopramide Combined with Dexamethasone and Diphenhydramine. Randomized Open Parallel StudyAapro, M.S.; Froidevaux, P.; Roth, A.; Alberto, P 116

Management of Low-Grade Lymphomas in Hong KongChineseLiang, R.; Chiu, E.; Loke, S.L 121

Lower Survival in Metastatic Cancer Patients with ReducedInterleukin-2 Blood Concentrations. Preliminary ReportLissoni, P.; Barni, S.; Rovelli, F.; Tancini, G 125 Leukocyte Alkaline Phosphatase and Carcinoembryonic Antigen in Colorectal Cancer Patients (Usefulness in the Assessment of the Stage)

Walach, N.; Guterman, A.; Zaidman, J.L.; Kaufman, S.;Scharf, S 128

Safety of High-Dose Vitamin A. Randomized Trial on Lung Cancer Chemoprevention

Pastorino, U.; Chiesa, G.; Infante, M.; Soresi, E.; Clerici, M.; Valente, M.; Belloni, P.A.: Ravasi, G $\quad 131$

Possible Mechanism for the Cocarcinogenic Effect of BileAcids: Increased Intracellular Uptake of Methylcholan-threne by C3H/10T1/2 Fibroblasts in vitroSugezawa, A.; Kaibara, N 138 Alkaline Phosphatase Activity in Human and Rat Liver Tumors 
Kovalszky, I.; Kralovanszky, J.; Jeney, A.; Lapis, K;Karacsonyi, S.; Szecheny, A 144

Expression of c-myc Gene Product in Gastric CarcinomaNinomiya, I.; Yonemura, Y.;

Matsumoto, H.; Sugiyama, K; Kamata, T.; Miwa, K; Miyazaki, I.; Shiku, H 149

Sequential DNA Flow Cytometry in Metastatic Malignant Melanoma

Bartkowiak, D.; Otto, F.; Schumann, J.; Lippold, A.; Drep-per, H 154

Human Colon Cancer Tissues Are More Sensitive than RectalCancer Tissues to Antitumor

Drugs in vitroUeo, H.; Maehara, Y.; Saito, A.; Sakaguchi, Y.; Kohnoe, S.;Sugimachi, K 158

Immunocytochemical Staining of Proliferating Cells in Endo-scopically Biopsied Tissues of

Gastric Carcinomas with Monoclonal Antibody Ki-67

Yonemura, Y.; Kimura, H.; Ooyama, S.; Kamata, T.;Yamaguchi, A.; Matsumoto, H.; Ninomiya,

I.; Miyazaki, 1162

Nucleolar Organizer Regions in Soft Tissue Sarcomas

Wrba, F.; Augustin, I.; Fertl, H 166

Adriamycin-Induced Neoplastic Lesions in the Egyptian Toad Bufo regidaris

El-Mofty, M.M.; Khudoley, V.V.; Sakr, S.A.; Osman, S.L;Toulan, B.A 171

Book Reviews 175

No. 3

Original Paper

Effects of Carotenoid Administration on Bladder Cancer Prevention

Mathews-Roth, M.M.; Lausen, N.; Drouin, G.; Richter, A.;Krinsky, N.I 177

Flow Cytometry Analysis of T Cell Subsets in Skin of Patients with Specific Cutaneous

Manifestation of B Non-Hodgkin Lymphoma

Ricevuti, G; Mazzone, A.; Pasotti, D.; Degiulio, R.;Sacchi, S 180

Primary Central Nervous System Lymphoma. A Report of 9 Cases and Review of the Literature Pittman, KB.; Olweny, C.L.M.; North, J.B.; Blumbergs, P.C. 184

Morphometric Diagnosis of Bladder Tumor

Yang, Q.; Xia, Y.; Wang, Z.; Wang, G; Ding, S.; Shi, D.;Liu, W 188

Aflatoxins in Sera from Patients with Lung Cancer

Cusumano, V 194

Research on the Differentiation of Human and Murine Neuroblastoma CellsBusse, E.; Bartsch, O.; Kornhuber, B 196

Detection of Pleiotropic Drug Resistance by the Rapid Immunofluorescence Assay of Drug

Effects on the Cell SkeletonMujagic, H.; Mujagic, Z202

Significance of Postoperative Early Chemotherapy for Loco-regional Lymph Node Metastases of

Gastric and ColorectalCancerMorimoto, H.; Tanigawa, N 210

Effects of Cytotoxic Chemotherapy on Ovarian and Adrenal Steroidogenesis in Pre-Menopausal

Breast Cancer PatientsDowsett, M.; Richner, J 215

Correlation between Histochemically Assessed Hormonal Receptor Content and Clinical Course

in Breast Cancer. Presentation of 1,005 Cases

Gottardi, O.; Baiocchi, C; Ferrari, M.; Franchi, L.; Gam-bacorta, M.; Landonio, G; Pinna, N.;

Ghislandi, E. ... 221

A Double-Blind Randomized Cross-Over Comparison ofHigh-Dose Prochlorperazine with High-

Dose Metoclopramide for Cisplatin-Induced EmesisAkhtar, S.S.; Bano, Z.A.; Bhat, G.M.; Bhat, M.A 226

Epirubicin and DTIC (EDIC) for Advanced Soft-Tissue Sarcomas Lopez, M.; Carpano, S.; Di

Lauro, L.; Vici, P.; Conti, E.M.S. 230 
The Relationship of the Proliferating Cell Nuclear Antigen Protein to m-

Diamminedichloroplatinum(II) Resistance of a Murine Leukemia Cell Line P388/CDDP Haneda, H.; Katabami, M.; Miyamoto, H.: Isobe, H.: Shimi-zu, T.; Ishiguro, A.; Moriuti, T.; Takasaki, Y.; Kawakami, Y. 234

Effect of Canthaxanthin on Chemically Induced Mammary Carcinogenesis Grubbs, C.J.; Eto, I.; Juliana, M.M.; Whitaker, L.M. ... 239

Low Uracil Concentration in the Liver Might Be Responsible for the Decreased Antineoplastic Activity of Fluoropyrim-idines in Mice with CCl4-Induced Chronic Liver Dysfunction Tsubono, M.; Nio, Y.; Imai, S.; Shiraishi, T.; Morimoto, H.; Tseng, C.-C; Kawabata, K; Fukumoto, M.; Tobe, T. 246

Fig. 1. Poorly differentiated NPC with lymphoinfiltration. HE. x 312. Note carcinoma cell (T), eosinophil (E), and plasma cell (P).

Fig. 2. a Distribution of T cells reactive for CD3 ( x 312) in NPC tissues. Note those reactive T cells which occurred as clusters in stromatous tissues (S) and those (arrow) which infiltrated the tumor nests (T). b Secondary lymphofollicles of CD19-reactive B lymphocyte in stroma of NPC tissues x 125.

Fig. 3. Restricted patterns of CD21 reactivity exhibited by squamous epithelium (a; x 312), and columnar epithelium (b; x 250) in the paratumorous areas of NPC tissues.

Fig. 4. CD23 expression by NPC cells (a; x312); columnar epithelium (b; x 312), and squamous epithelium (c; x 312) in NPC tissues.

Contents

$\mathrm{V}$

Sister Chromatid Exchanges in Lymphocyte Cultures of Patients Previously Treated with DibromodulcitolAnsell, S.M.; Jansen van Rensburg, C.E.; Rapoport, B.L.;Gresse, P.; Cloete, E.V.; van Staden, A.M.; Stevens, K.;Falkson, C.I.; Falkson, G 253

Modulation of Cervical Carcinogenesis by Tamoxifen in aMouse Model SystemSengupta, A.;

Dutta, S.; Mallick, R 258

Book Reviews 262

No. 4

Original Paper

Mitoxantrone as Second-Line Single Agent in Metastatic

Breast Cancer

Stein, M.; Borovik, R.; Robinson, E 265

Simultaneous Cis-Platinum and Radiotherapy in Inoperable

or Locally Advanced Squamous Cell Carcinoma of the

Head and Neck

Gasparini, G.; Pozza, F.; Recher, G.; Panizzoni, G.A.;

Cristoferi, V.; Squaquara, R.: Dal Fior, S 270

Relative Importance of Dose, Body Surface Area, Sex, and Age

for 5-Fluorouracil Clearance

Port, R.E.; Daniel, B.; Ding, R.W.; Herrmann, R 277

Treatment of 5-Fluorouracil-Induced Stomatitis by Allopuri-

nol Mouthwashes

Elzawawy, A 282

Application of Bromodeoxyuridine (BrdU) and Anti-BrdU 
Monoclonal Antibody for the in vivo Analysis of Proliferative Characteristics of Human

Leukemic Cells in Bone

Marrows

Nakamura, S.; Takeda, Y.; Kanno, M.; Yoshida, T.;

Ohtake, S.; Kobayashi, K.; Okabe, Y.; Matsuda, T 285

Nasopharyngeal Carcinoma and Lymphoinfiltration

Zong, Y.S.; Lin, H.; Choy, D.T.K.; Sham, J.S.T.; Wei, W.;

Chan, K.H.; Ng, M.H 290

Plasma Thrombosis-Inducing Activity in 120 Patients with

Primary Lung Cancer

Nakanishi, M.; Yagawa, K.; Hayashi, S.; Ogino, H.; Ogata,

K.; Yatsunami, J.; Miyagawa, Y.; Hirano, H.; Miyazaki,

M.; Yoshida, M.; Ichinose, Y.; Hara, N.; Ohta, M 297

Cancer Patterns at Medical Centers in Israel and the West

Bank

Horn, Y.; Zippin, C; Salhab, A.R.; Horani, Y

301

Familial Nonmedullary Thyroid Cancer

Ron, E.; Kleinerman, R.A.; LiVolsi, V.A.; Fraumeni, J.F., Jr. 309 Differences in the Kinetics of DNA Repair in Cancer Patients

and Healthy Controls

Kovacs, E.; Langemann, H 312

The Effect of Sodium Perchlorate and Ionizing Irradiation on

the Thyroid Parenchymal and Pituitary Thyrotropic Cells

Pajer, Z.; Kalisnik, M 317

Serum Sialyl-Tn Antigen Levels in Patients with Digestive

Cancers

Motoo, Y.; Kawakami, H.; Watanabe, H.; Satomura, Y.;

Ohta, H.; Okai, T.; Makino, H.; Toya, D.; Sawabu, N. . . 321

Anthracycline Cardiotoxicity: In vivo and in vitro Effects on Biochemical Parameters and Heart Ultrastructure of the Rat

Cini Neri, G.; Neri, B.; Bandinelli, M.; Del Tacca, M.;Danesi, R.; Riccardi, R

Comparative Pharmacokinetics of Chlorambucil and Predni-mustine after Oral

AdministrationLoos, U.; Musch, E.; Malek, M.; Riedel, E 334

Flowcytometric Measurement of the Cell Cycle of Experimental Tumors: Some Devices for Accurate Measurement of Proliferative Activity

Tsugita, M.; Tsuru, S.; Takasaki, T.; Shinomiya, N.; Kobayashi, S.; Hanyu, F

Carcinogenic Effect of Force-Feedings and Extract of BlackPepper (Piper nigrum) in Egyptian

Toads (Bufo regularis)El-Mofty, M.M.; Khudoley, V.V.; Shwaireb, M.H 347

Book Reviews 351

No. 5

Original Paper

Association of Epirubicin, Etoposide and Cisplatin in Gastric

Cancer. A Phase II Study

Barone, C; Cassano, A.; Astone, A.; Ricevuto, E.; Fontana,

T.; Noviello, M.R.; Garufi, C; Pacelli, F.; Grieco, A. . . 353 Acute Gastroduodenal Mucosal

Injury after Cisplatin plus 
Etoposide Chemotherapy. Clinical and Endoscopic Study

Sartori, S.; Nielsen, I.; Maestri, A.; Beltrami, D.; Trevisani,

L.; Pazzi, P 356

Combined Chemotherapy and Radiotherapy for Lymphomas

of Waldeyer's Ring

Liang, R.;Chiu, E.;Todd, D.;Chan, T.K.;Choy, D.;Loke, S.L. 362 Role of Recombinant Alpha-

Interferon in the Treatment of

Advanced Cutaneous Malignant Melanoma

Mughal, T.I.; Thomas, M.R.; Robinson. W.A

Intermediate Dose of Intravenous Melphalan in Advanced

Multiple Myeloma

Tsakanikas, S.; Papanastasiou, K.; Stamatelou, M.; Ma-

niatis, A 369

Influence of Serum Derived from Patients with Head and

Neck Cancer on Natural Killer Cell Activity

Kumazawa, H.; Hess, M 372

Coagulation Disorders and Tumor Markers in the Diagnosis of

Pancreatic Cancer

Abbasciano, V.; Graziano, L.; Guerra, S.; Mazzotta, D.;

Pollinzi, V.; Gilli, G.; Zavagli, G 377

Diagnosis of Anal Carcinoma - Doctor's Finger Still the

Best?

Tanum, G.; Tveit, K.; Karlsen, K.0 383

Hyperimmunoglobulmemia D following Cancer Chemotherapy

Azuma, E.; Masuda, S.; Hanada, M.; Zhou, Y.-W.; Zhang,

S.-L.; Shibata, T.; Komada, Y.; Sakurai, M 387

Acute and Delayed Emesis after Cisplatin-Based Regimen:

Description and Prevention

Louvet, C; Lorange, A.; Letendre, F.; Beaulieu, R.; Pretty,

H.M.; Courchesne, Y.; Neemeh, J.A.; Monte, M.; Latreille, J. 392

$\mathrm{VI}$

Contents

Randomized Trial for the Control of Acute Vomiting in Cis-platin-Treated Patients: High-Dose Metoclopramide withDexamethasone and Lorazepam as Adjuncts versus High-Dose Alizapride plus Dexamethasone and Lorazepam.Study of the Incidence of Delayed EmesisMoreno, I.;

Rosell, R.; Abad-Esteve, A.; Barnadas, A.;Carles, J.; Ribelles, N 397

Control of Refractory, Chemotherapy-Induced Emesis with the Serotonin Antagonist

Ondansetron (GR38032F) Campora, E.; Vidili, G.; Oliva, C; Ardizzoni, A.; Rosso, R. 403

Dairy Products and the Risk of Prostatic Cancer

La Vecchia, C; Negri, E.; D’Avanzo, B.; Franceschi, S.;Boyle, P 406

Results of a Nationwide Study on the Three-Field LymphNode Dissection of Esophageal

CancerIsono, K.; Sato, H.; Nakayama, K\ 411

Immunohistochemical Detection of Estrogen Receptors inParaffin Sections of Human Thyroid

TissuesHiasa, Y.; Nishioka, H.; Kitahori, Y.; Yane, K.; Nakaoka, S.; Ohshima, M.; Konishi, N.;

Nishii, K.; Kitamura, M.;Sugimura, M 421 
Pregnancy-Induced Cytotoxicity of Splenocytes against Mammary Tumor Cells in RatsChakravarty, P.K.; Ghosh, S.K.; Sinha, D.K 425

Importance of Administration Method in High-Dose Anticancer Chemotherapy from

Toxicological Standpoint in Rats Mizushima, Y.; Konishi, K.; Morikage, T.; Yano, S. ... 431

Book Reviews $\quad 438$

No. 6

Original Paper

Long-Term Survivors in Resected and Nonresected Small Cell Lung Cancer

Hara, N.; Ichinose, Y.; Kuda, T.; Asoh, H.; Yano, T.;Kawasaki, M.; Ohta, M 441

Clinical Results with the Pineal Hormone Melatonin in Advanced Cancer Resistant to Standard

Antitumor TherapiesLissoni, P.; Barni, S.; Cattaneo, G.; Tancini, G.; Esposti, G.; Esposti, D.;

Fraschini, F 448

Treatment of Myelodysplastic Syndromes with Orally Administered 1 -(3-D-

Arabinofuranosylcytosine-5'-StearylphosphateOhno, R.; Tatsumi, N.; Hirano, M.; Imai, K.;

Mizoguchi, H.; Nakamura, T.; Kosaka, M.; Takatsuki, K.; Yamaya, T.;Toyama, K.; Yoshida, T.;

Masaoka, T.; Hashimoto, S.;Ohshima, T.; Kimura, I.; Yamada, K.; Kimura, K 451

Treatment of Resistant Hodgkin's Disease with CCNU, Eto-poside and Prednimustine

(CEP)Szanto, I.; Fleischmann, T.; Eckhardt, S 456

Ifosfamide. Methotrexate and 5-Fluorouracil for Pretreated Advanced Breast Cancer

Becher, R.; Hofeler, H.; Kloke, O.; May, D.; Wandl, U.; Niederle, N.; Richter, R.; Scheulen, M.E.; Schmidt, C.G. 459

Immunologic Changes in Renal Cell Carcinoma Patients Receiving Gamma Interferon

Barna, B.P.; Thomassen, M.J.; Sergi, L; Murthy, S.; Bu-kowski, R.M 464

Modulation of Methotrexate Cytotoxicity with Natural Interferon upon Human Leukemia Cell

Line HL-60Sur, P.; Matsuo, Y.; Otani, T.; Minowada, J 469

Protective Effect of Elastase on cis-Platinum-Induced RenalToxicitySuzuki, M.; Sekiguchi, I.;

Tamada, T.; Tsuru, S 474

Nasopharyngeal Carcinoma: Role of Marrow Biopsy at DiagnosisSham, J.S.T.: Chan, L.C.;

Loke, S.L.; Choy. D 480

Follicular Cancer of the Thyroid Gland

Szanto, J.; Ringwald, G.; Karika, Z.: Liszka. G.; Peter, I.;Daubner, K

Diet and Urine Estrogens among Postmenopausal Women

Katsouyanni, K.; Boyle, P.; Trichopoulos, D 490

Reticulum Cell Sarcoma: Two Complete 'Spontaneous' Regressions, in Response to High-Dose

Ascorbic Acid Therapy. A Report on Subsequent ProgressCampbell, A.; Jack, T.; Cameron, E 495

Effects of Combined Therapies with Protein-Bound Polysaccharide (PSK, Krestin”) and

Fluorinated Pyrimidine Derivatives on Experimental Liver Metastases and on theImmunologic

Capacities of the HostsTsuru, S.; Shinomiya, N.: Katsura. Y.; Gotoh. M.: Nori-take, M.;

Nomoto. K 498

Effects of Retinoid Glucuronides on Mammary Gland Development in Organ Culture Mehta,

R.G.; Barua, A.B.: Olson, J.A.; Moon, R.C. ... 505

Fractional Incorporation of Radionucleotides, a Marker of in vitro Tumor Cell Chemosensitivity

in Colorectal Cancer Franchi, F.; Seminara, P.; Giannarelli, D.; Konovalova, N. 510

B. Book Reviews 517

Author Index 520 
